\title{
PENYESUAIAN DIRI DITINJAU DARI RELIGIUSITAS PADA PENGGUNA NARKOBA DI BRSKP (BALAI REHABILITASI SOSIAL KORBAN PENYALAHGUNAAN) NAPZA "INSYAF" SUMATERA UTARA
}

\author{
SELF ADJUSTMENT IN TERMS OF RELIGIOSITY ON DRUG USERS IN THE BRSKP \\ NAPZA "INSYAF" NORTH SUMATRA
}

\author{
Oleh: \\ Jessica Nissi Pangaribuan ${ }^{1}$ \\ Sri Hartini ${ }^{2}$ \\ Winida Marpaung ${ }^{3}$
}

\begin{abstract}
Submitted:

12 November 2019

Revision:

11 Januari 2020

Accepted:

16 Januari 2020

This study aims to find out relationship between religiosity and self adjustment. The Hypothesis of this study states that there is a positive correlation between religiosity and self adjustment, assuming that the higher religiosity, the higher will self adjustment and conversely the lower religiosity, the lower will self adjustment. The subjects of this study were 180 drug users in the BRSKP Insyaf. The data analyze used is product moment Correlation with SPSS 17 for Windows. The results of data analyze showed that the correlation coefficient was 0.390 with $p 0.000$ ( $p<0.05$ ). It shows that there is a positive relationship between religiosity and self adjustment. These results indicate that the contribution of a given variable of religiosity to self adjustment is at 15.2 percent, while the remaining 84.8 percent is influenced by othe factors not examined. From these results, it is concluded that the hypothesis stating that there is a positive correlation between religiosity and self adjustment is acceptable.

Keywords: Drug Users; Religiosity; Self Adjustment.
\end{abstract}

ABSTRAK

Penelitian ini bertujuan untuk mengetahui hubungan antara religiusitas dengan penyesuaian diri. Hipotesis yang diajukan dalam penelitian ini adalah ada hubungan positif antara religiusitas dan penyesuaian diri dengan asumsi semakin tinggi religiusitas, maka semakin tinggi penyesuaian diri dan sebaliknya. Subjek penelitian yang digunakan dalam penelitian ini adalah korban penyalahgunaan narkoba di BRSKP (Balai Rehabilitasi Sosial Korban Penyalahgunaan) Napza "Insyaf" Sumatera Utara sebanyak 180 orang. Analisis data yang digunakan adalah menggunakan korelasi Product Moment melalui bantuan SPSS 17 for Windows. Hasil analisis data menunjukkan koefisien korelasi sebesar 0.390 dan nilai signifikansi sebesar $0.000(\mathrm{p}<0.05)$. Ini menunjukkan ada hubungan positif antara religiusitas dengan penyesuaian diri. Hasil penelitian ini menunjukkan bahwa sumbangan yang diberikan variabel religiusitas terhadap penyesuaian diri sebesar 15.2 persen, selebihnya 84.8 persen dipengaruhi oleh faktor lain yang tidak diteliti. Dari hasil penelitian ini dapat disimpulkan bahwa hipotesis penelitian ada hubungan positif antara religiusitas dengan penyesuaian diri dapat diterima.

Kata kunci: Penyesuaian Diri; Religiusitas; Pengguna Narkoba

\footnotetext{
${ }^{1}$ Jessica Nissi Pangaribuan Universitas Prima Indonesia, Email: jessicanissi31@gmail.com

${ }^{2}$ Sri Hartini, Universitas Prima Indonesia, Email : srihartini_psikologi@ unprimdn.ac.id

${ }^{3}$ Winida Marpaung, Universitas Prima Indonesia, Email : winida.marpaung@ gmail.com
} 


\section{PENDAHULUAN}

Pada zaman sekarang ini, pergaulan dan gaya hidup masyarakat terutama di kalangan remaja semakin mengkhawatirkan banyak peristiwa buruk yang terjadi dan tidak dapat dihindari. Menurut Gunarsa (2004) pergaulan memang sangat mempengaruhi tingkah laku remaja apalagi ajakan teman sebaya. Sangatlah baik jika remaja dapat menolak ajakan yang dirasa kurang tepat, akan tetapi pada kenyataannya banyak remaja yang masih sangat banyak tidak mampu dan tidak berani menolak ajakan tersebut. Misalnya remaja mengenal rokok, narkoba, dan alkohol, dalam mengikuti perilaku teman-temannya. Rokok, narkoba dan alkohol bersifat adiksi (ketagihan), apabila sudah ketagihan, sangat sulit untuk melepaskan diri dari barang berbahaya ini. Ketagihan terhadap barang berbahaya ini akan membuat seseorang menjadi adiksi atau kecanduan.

Menurut Gordon dan Gordon (2000) ketergantungan obat/alkohol atau obat terlarang ini merupakan suatu gangguan atau penyakit bagi si pengkonsumsi yang bersifat mental, fisik dan emosional, sehingga menimbulkan dampak merasa tidak mampu bagi dirinya untuk menghentikan kecenderungan menggunakan obat terlarang tersebut. Secara sederhana, ketergantungan obat dapat diartikan: "saya tidak dapat berhenti ( $i$ can't stop). Semua obatobatan dan alkohol yang sangat kuat pengaruhnya yang menimbulkan ketergantungan, misalnya putaw (heroin), shabu-shabu, cocaine, marijuana, nipan, ecstacy, LSD, mushroom, barbiturates, ampehetamines, dan hallucinogen. Ini merupakan ketergantungan, awalnya mungkin tidak setiap hari menggunakan alkohol atau obat. Akan tetapi kebiasaan yang terus menerus ini akan berubah menjadi ketagihan apabila terus dilakukan dan akhirnya menjadi tidak dapat lepas dari alkohol atau obat (dalam Dariyo, 2004).

Narkotika menurut UU RI No 22/1997 yaitu merupakan obat-obatan yang berasal dari tanaman dan bukan tanaman baik sintetis maupun semisintetis yang dapat menyebabkan perubahan bagi yang mengkonsumsi dalam hal penurunan kesadaran, menghilangkan rasa nyeri, dan dapat membuat adiksi atau ketagihan bagi yang mengkonsumsi. Mengingat dampak negatif dari penyalahgunaan barang berbahaya ini yang dapat merusak generasi masa depan maka dicarikan upaya-upaya lain untuk menghindari pidana penjara, antara lain berupa memakai peraturan tindak pidana denda dan pidana kerja sosial bagi yang terbukti melakukan penyalahgunaan narkoba. Dan secara khusus berdasarkan Pasal 54 Undang-Undang Nomor 35 Tahun 2009 tentang Narkotika yaitu menjelaskan bahwa pecandu barang terlarang maupun yang korban penyalahgunaan barang berbahaya ini wajib menjalani rehabilitasi medis maupun rehabilitasi sosial (Tarigan, 2017).

Masalah penyalahgunaan narkotika di Indonesia semakin banyak terjadi, mulai dari masyarakat yang tergolong dalam ekonomi rendah sampai berekonomi tinggi. Badan Narkotika Nasional (BNN) mempunyai data terkait penyalahgunaan narkotika dan obat-obatan terlarang (narkoba). Kepala Bidang Pencegahan dan Pemberdayaan Masyarakat BNN Sumut Tuangkus Harianja menyatakan bahwa dari 14 juta masyarakat di Sumut diperkirakan ada 33 kabupaten/kota dan sekitar 350 ribu sebagai korban penyalahgunaan maupun pengguna narkoba. Dimana, ini angka yang cukup tinggi dan miris. Lebih lanjut, memperkirakan sekitar 10 ribu orang di setiap kabupaten/kota yang telah menjadi korban penyalahgunaan narkoba (tribunnews.com, 2017).

Kasus yang sama juga terjadi pada pengguna narkoba di BRSKP (Balai Rehabilitasi Sosial Korban Penyalahgunaan) Napza "Insyaf" Sumatra Utara. Berdasarkan hasil dari 
wawancara yang telah dilakukan oleh peneliti terhadap beberapa korban penyalahgunaan narkoba yang sedang menjalani rehabilitasi, mengenai penyalahgunaan narkoba yang mereka lakukan, mereka mengakui dengan menggunakan narkoba mereka dapat merasakan kenikmatan tersendiri dalam mengkonsumsi narkoba, misalnya jadi lebih bersemangat dalam bekerja, tidak merasa capek, dan lebih merasa percaya diri, serta keberanian yang dirasa dapat semakin meningkat. Namun, dalam penggunaannya narkoba mempunyai dampak negatif dan buruk yaitu mereka yang mengkonsumsinya yaitu selalu merasa amat curiga secara berlebihan pada semua orang yang ada disekitarnya, ditandai dengan adanya berbagai tingkah laku ataupun perilaku serba salah, misalnya si pengguna memiliki perilaku tidak terarah, terlalu emosional, adanya sikap tidak realistis, mudah sekali untuk marah dan juga sangat agresif. Dimana penyalahgunaan obat-obatan ini diawali karena adanya pengaruh lingkungan yang buruk.

Sobur (2013) menjelaskan bahwa penyesuaian diri merupakan tindakan seseorang untuk dapat mengubah diri sesuai dengan keadaan lingkungan, dan mengubah lingkungan sesuai dengan keadaan keinginan diri. Jadi ada artinya yang "pasif" dan "aktif", di mana pasif tindakan kita ditentukan oleh lingkungan, dan yang "aktif", di mana kita yang mempengaruhi lingkungan sekitar kita. Adanya proses dipengaruhi atau yang mempengaruhi lingkungan.

Menurut Kartono (2000), menjelaskan penyesuaian diri adalah usaha seseorang untuk dapat meraih harmoni dalam dirinya sendiri dan juga pada lingkungan ia berada. Sehingga rasa permusuhan, dengki, iri hati, prasangka, stress, frustrasi kemarahan dan lain-lain emosi negatif lainnya sebagai respons pribadi yang tidak sesuai dan kurang efisien bisa dihilangkan. Dalam pengertian yang lebih luas yaitu kemampuan seseorang untuk dapat mempertahankan eksistensinya, atau bisa survive atau bertahan, dan mendapatkan kesejahteraan secara jasmaniah dan rokhaniah. Juga dapat diartikan sebagai konformitas, yaitu konform atau sesuai dengan norma-norma cerminan hatinya. Dimana nilai-nilai religius memberikan kesehatan mental, dalam suatu keadaan yang mendorong untuk berperilaku dan bertindak dalam kehidupan sehari-hari sesuai dengan kadar ketaatannya terhadap ajaran agama atau religi.

Yusuf (2004) menjelaskan pada dasarnya kita manusia adalah makhluk yang beragama (homoreligius). Homoreligius yaitu makhluk yang memiliki rasa keagamaan dan kemampuan untuk memahami nilai-nilai religi dalam ajarannya, baik yang bersifat ritual personal maupun ibadah dan kegiatan sosial dalam agama, sama halnya seperti menjalani hubungan antara manusia dan lingkungan yang bermanfaat bagi kesejahteraan umat. Jadi, pada dasarnya setiap manusia merupakan makhluk yang religius.

Salah satu faktor yang mempengaruhi penyesuaian diri yaitu persepsi. Penelitian ini yang dilakukan oleh Rokhmatika dan Darminto (2013) pada siswa kelas unggulan dengan jumlah 150 subjek. Hasil penelitian menunjukkan bahwa adanya hubungan positif antara persepsi dengan penyesuaian diri yang berarti semakin baik persepsi dalam penilaian dan pemahaman terhadap lingkungan maka akan semakin baik penyesuaian diri yang dimilikinya untuk mengatasi kebutuhan, dan ketegangan.

Selain persepsi faktor lain yang mempengaruhi penyesuaian diri ialah religiusitas. Dibuktikan dengan penelitian yang dilakukan oleh Dian dan Endang (2017) kepada siswa kelas VII Yayasan Pondok Pesantren Futuhiyyah Mranggen Kabupaten Demak, terungkap bahwa ada hubungan yang positif antara religiusitas dengan penyesuaian diri. Hasil penelitian ini menunjukkan bahwa adanya usaha setiap individu dalam merespon mentalnya dalam mengatasi kebutuhan-kebutuhannya seperti depresi, stress dan frustasi, sehingga usaha respon 
yang baik membuat terwujudnya keselarasan antara tuntutan dari dalam diri dan keberadaanya. Dalam hal ini, siswa dengan religiusitas yang tinggi lebih mampu menghadapi berbagai konteks situasi tanpa dipengaruhi oleh persoalan yang dihadapi.

Hasil yang sama ditemukan dalam penelitian yang dilakukan oleh Andriyanti (2015) terhadap siswa SMP Negeri 3 Pakem dengan jumlah 54 subjek. Membuktikan bahwa religiusitas merupakan faktor yang mempengaruhi penyesuaian diri seseorang. Melalui penelitiannya terungkap bahwa seseorang memiliki penyesuaian diri yang baik, jika memiliki kemampuan melakukan respon yang efisien, dan sehat. Dalam hubungan antara individu dengan penciptanya menentukan bahwa suatu penyesuaian diri dapat dikatakan baik. Hal ini menjelaskan bahwa agama mempunyai kaitan yang erat dengan penyesuaian diri. Hasil yang diperoleh dari penelitian ini adalah adanya hubungan positif antara religiusitas dengan penyesuaian diri, yang berarti jika tinggi religiusitasnya maka akan semakin mampu menyesuaikan diri, begitupun sebalkinya jika rendahnya kualitas religiusitas yang dimilikinya maka semakin sulit menyesuaikan diri.

Hasil penelitian juga sama pada penelitian yang dilakukan oleh Nadzir dan Wulandari (2013) pada siswa pondok pesantren dengan jumlah subjek 132 subjek telah membuktikan bahwa religiusitas merupakan faktor yang mempengaruhi penyesuaian diri seseorang. Yaitu semakin tinggi tingkat religiusitas seseorang maka juga akan semakin mampu atau mudah bagi individu tersebut untuk menyesuaikan diri dengan kebutuhannya. Begitu juga sebaliknya, rendahnya religiusitas yang dimiliki individu tersebut maka ia juga akan cenderung lebih sulit untuk menyesuaikan diri dengan lingkungan dan kebutuhannya. Dengan demikian nilai religius memiliki sumbangan yang berarti terhadap perkembangan penyesuaian diri individu.

Hal tersebut sesuai dengan pendapat Jalaluddin (2007), religiusitas merupakan suatu keadaan yang mendorongnya individu dalam dirinya untuk bertingkah laku dalam kehidupan sehari-hari sesuai dengan ketaatannya terhadap agamanya. Bahwasannya rasa bahagia yang mendalam itu erat hubungannya dengan rasa keagamaan (perasaan religius), dan cenderung mengusir segala perasaan yang negatif, sikap yang salah, dan pengalaman-pengalaman traumatis. Oleh karena itu, nilai religiusitas memberikan dampak bagi penyesuaian diri seseorang. Bahwasannya rasa bahagia yang mendalam itu erat hubungannya dengan rasa keagamaan (perasaan religius), dan cenderung mengusir segala perasaan yang negatif, sikap yang salah, dan pengalaman-pengalaman traumatis yang dapat menggerogoti integritas individu.

Religiusitas juga tidak hanya berkaitan dengan pengalaman aktifitas yang kelihatan tapi juga aktifitas yang tak kelihatan yang terjadi dalam hati seseorang, sehingga nilai religius dapat meliputi berbagai macam dimensi (Ancok \& Suroso, 2005). Dari penjelasan diatas dapat disimpulkan bahwa religiusitas sebagai suatu kegiatan yang ada dalam diri individu, yang dapat mendorongnya untuk bertingkah laku religius sesuai dengan kadar ketaatannya terhadap agama.

Berdasarkan uraian-uraian diatas, maka peneliti tertarik untuk meneliti hubungan antara religiusitas dengan penyesuaian diri pada pengguna narkoba di BRSKP (Balai Rehabilitasi Sosial Korban Penyalahgunaan) Napza “Insyaf' Sumatera Utara. Penelitian ini bertujuan untuk megetahui hubungan antara religiusitas dan penyesuaian diri. Manfaat praktis yang diharapkan dari penelitian ini jika hipotesis diterima adalah bagi pengguna narkoba agar dapat mampu menghadapi masalah-masalah yang menyebabkan stres, cemas dan ketidaknyamanan selama 
dalam menjalani rehabilitasi. Berusahalah semaksimal mungkin untuk dapat memiliki kemampuan dalam menyesuaikan diri dengan baik selama proses rehabilitasi sampai selesai, sehingga tujuan rehabilitasi dapat di selesaikan dengan baik. Hipotesis yang diajukan dalam penelitian ini adalah terdapat hubungan positif antara religiusitas dengan penyesuaian diri. Dengan asumsi semakin berkualitas tingkat religiusitasnya maka akan semakin mampu menyesuaikan diri, sebaliknya semakin rendah kualitas religiusitasnya maka akan semakin sulit menyesuaikan diri.

\section{METODE PENELITIAN}

Variabel terikat yang dipakai dalam penelitian ini adalah penyesuaian diri, sedangkan variabel bebas adalah religiusitas.

Populasi dalam penelitian ada sebanyak 180 orang pengguna narkoba di BRSKP (Balai Rehabilitasi Sosial Korban Penyalahgunaan) Napza “Insyaf' Sumatera Utara. Dengan jumlah populasi sebesar 180 orang, maka penelitian menggunakan teknik total sampling yaitu dengan teknik pengambilan sampel, dimana jumlah dari sampel sama dengan jumlah populasi.

Teknik pengumpulan data yang dipakai dalam penelitian ini menggunakan metode pembagian skala untuk mengukur penyesuaian diri dan religiusitas. Jenis skala yang digunakan dalam penelitian ini adalah skala likert. Penelitian ini menggunakan skala likert yang mengacu pada indikator penyesuaian diri yang diuraikan oleh Siswanto (2007), yang diantaranya: memiliki persepsi yang akurat terhadap realita, kemampuan untuk beradaptasi dengan tekanan atau stres dan kecemasan, mempunyai gambaran diri yang positif tentang dirinya, kemampuan untuk mengekspresikan perasaannya, relasi interpersonal baik, sehingga memungkinkan seorang dapat menyesuaikan diri dengan baik. Yang terdiri dari 50 butir pernyataan, dengan 25 butir pernyataan favourable dan 25 butir pernyataan unfavourable. Dengan daya gerak dari 0.306-0.613 dengan estimasi reliabilitas Alpha sebesar 0.859.

Skala religiusitas yang digunakan dalam penelitian ini adalah dimensi-dimensi religiusitas dikemukakan oleh Glock dan Stark (dalam Ghufron \& Risnawati, 2015) yang diantaranya: dimensi keyakinan (the ideological dimension), dimensi peribadatan atau praktik agama (the ritualistic dimension), dimensi feeling atau penghayatan (the experiencal dimension), dimensi pengetahuan agama (the intellectual dimension), dimensi effect atau pengamalan (the consequential dimension). Yang terdiri dari 50 butir pernyataan, dengan 25 butir pernyataan favourable dan 25 butir pernyataan unfavourable. Dengan daya gerak dari 0.326-0.613 dengan estimasi reliabilitas Alpha sebesar 0.908.

Teknik analisis yang digunakan untuk menguji hipotesis sekaligus menganalisis data hasil penelitian ini adalah dengan menggunakan metode korelasi Product Moment (Pearson Corellation).

\section{HASIL DAN PEMBAHASAN}

Sebelum melakukan uji hipotesis, terlebih dahulu dilakukan uji asumsi untuk mengetahui ada tidaknya penyimpangan data yang diperoleh dari alat pengumpulan data. Uji asumsi yang digunakan dalam penelitian ini adalah uji normalitas dan uji linieritas. 
Tabel 1.

Hasil Uji Normalitas

\begin{tabular}{cccccc}
\hline Variabel & SD & K-SZ & Sig. & P & Keterangan \\
\hline Penyesuaian diri & 12.810 & 1.287 & 0.120 & $\mathrm{P}>0,05$ & sebaran normal \\
\hline Religiusitas & 16.260 & 1.364 & 0.049 & $\mathrm{P}>0,05$ & sebaran normal \\
\hline
\end{tabular}

Uji normalitas dilakukan bertujuan agar dapat mengetahui apakah setiap variabel penelitian menyebar secara normal. Uji normalitas sebaran menggunakan uji Kolmogorov Smirnov Test (K-SZ). Data dikatakan berdistribusi normal jika $\mathrm{p}>0.05$. Variabel penyesuaian diri menunjukkan nilai K-SZ sebesar 1.287 dengan Sig sebesar 0.073 untuk uji 2 (dua) arah dan Sig sebesar 0.0365 untuk uji 1 (satu) arah ( $\mathrm{p}>0.05$ ), yang menjelaskan bahwa data pada variabel penyesuaian diri memiliki sebaran atau berdistribusi normal. Variabel religiusitas diperoleh koefisien KS-Z sebesar 1.364 dengan Sig sebesar 0.049 untuk uji 2 (dua) arah dan Sig sebesar 0.0245 untuk uji 1 (satu) arah ( $\mathrm{p}>0.05)$, yang berarti bahwa data pada variabel religiusitas memiliki sebaran atau berdistribusi normal. Berdasarkan hasil tersebut data variabel religiusitas memiliki sebaran atau berdistribusi normal karena $\mathrm{p}>0.05$.

Tabel 2.

\section{Hasil uji Linearitas}

\begin{tabular}{cccc}
\hline Variabel & F & P & Keterangan \\
\hline $\begin{array}{c}\text { Penyesuaian Diri } \\
\text { Religiusitas }\end{array}$ & 41.942 & 0.000 & Linear $(\mathrm{P}<0.05)$ \\
\hline
\end{tabular}

Berdasarkan pada Tabel 2 dapat dikatakan bahwa variabel penyesuaian diri dan religiusitas memiliki hubungan linear. Hal ini dapat terlihat dari nilai $\mathrm{P}$ yang diperoleh yaitu 0.000 maka $\mathrm{p}<0.05$ maka dapat disimpulkan adalah kedua variabel memiliki hubungan linear dan telah memenuhi syarat untuk dilakukan analisa korelasi Product Moment.

Apabia setelah uji asumsi diterima maka selanjutnya dilakukan uji hipotesis. Pengujian hipotesis dilakukan dengan menggunakan analisis Pearson Correlation. Hasil uji statistik dapat dilihat pada Tabel 3 .

Tabel 3.

Korelasi antara Religiusitas dengan Penyesuaian diri

\begin{tabular}{ccc}
\hline Analisis & Pearson Correlation & Signifikansi (p) \\
\hline Korelasi & 0.390 & 0.000 \\
\hline
\end{tabular}

Berdasarkan hasil analisis korelasi antara religiusitas dengan penyesuaian diri, diperoleh koefisien korelasi product moment sebesar 0.390 dengan $\mathrm{p}$ sebesar 0,000 ( $\mathrm{p}<0,05$ : Sig. 1-tailed). Hal ini menunjukkan bahwa adanya korelasi positif antara religiusitas dengan penyesuaian diri. Dari hasil perhitungan tersebut, maka hipotesis yang diajukan dalam 
penelitian ini menunjukkan adanya hubungan yang positif antara religiusitas dengan penyesuaian diri dinyatakan dapat diterima.

Tabel 4.

Sumbangan Efektif

\begin{tabular}{llrrr}
\hline & & & & \\
Model & R & R Square & \multicolumn{2}{c}{ Squsted $R$} \\
Square & Std. Error of the Estimate \\
\hline 1 & $.390^{\mathrm{a}}$ & .152 & .147 & 11.829 \\
\hline
\end{tabular}

Berdasarkan tabel 4 Model Summary Sumbangan efektif di atas, dapat disimpulkan dalam penelitian ini diperoleh koefisien determinasi sebesar 0.152. Berdasarkan hasil tersebut, dapat disimpulkan bahwa sumbangan 15.2 persen religiusitas mempengaruhi penyesuaian diri dan selebihnya 84.8 persen dipengaruhi faktor-faktor lain yang tidak diteliti pada penelitian ini.

Tabel 5.

Perbandingan Data Mean Empirik dan Hipotetik

\begin{tabular}{|c|c|c|c|c|c|c|c|c|}
\hline \multirow{2}{*}{ Variabel } & \multicolumn{3}{|c|}{ Empirik } & \multirow{2}{*}{ SD } & \multicolumn{3}{|c|}{ Hipotetik } & \multirow{2}{*}{ SD } \\
\hline & Min & Max & Mean & & Min & Max & Mean & \\
\hline $\begin{array}{c}\text { Penyesuaian } \\
\text { diri }\end{array}$ & 97 & 173 & 149.49 & 12.810 & 50 & 200 & 125 & 25 \\
\hline Religiusitas & 126 & 203 & 159.76 & 16.260 & 50 & 200 & 125 & 25 \\
\hline
\end{tabular}

Hasil analisis untuk skala penyesuaian diri, diperoleh mean empirik > mean hipotetik yaitu $149.49>125$, maka dapat disimpulkan bahwa penyesuaian diri subjek penelitian lebih tinggi dari pada populasi pada umumnya. Hasil analisis untuk skala religiusitas, diperoleh mean empirik mean hipotetik yaitu $159.76>125$ maka disimpulkan bahwa religiusitas subjek penelitian lebih tinggi dari pada populasi pada umumnya.

Tabel 6.

\section{Kategorisasi Data Penyesuaian Diri}

\begin{tabular}{ccccc}
\hline Variabel & $\begin{array}{c}\text { Rentang } \\
\text { Nilai }\end{array}$ & Kategori & Jumlah (n) & Persentase \\
\hline \multirow{2}{*}{$\begin{array}{c}\text { Penyesuaian } \\
\text { Diri }\end{array}$} & $\mathrm{x}<100$ & Rendah & 1 & $0.6 \%$ \\
\cline { 2 - 5 } & $100 \leq \mathrm{x}<150$ & Sedang & 87 & $48.3 \%$ \\
\cline { 2 - 5 } & $\mathrm{x} \geq 150$ & Tinggi & 92 & $51.1 \%$ \\
\hline
\end{tabular}

Berdasarkan Tabel 6 dapat dilihat bahwa subjek penyesuaian diri pada kategori rendah berjumlah 1 orang dengan persentase 0.6 persen, kategori sedang berjumlah 87 orang dengan persentase sebesar 48.3 persen sedangkan subjek penyesuaian diri yang masuk dalam kategori tinggi berjumlah 92 orang dengan persentase sebesar 51.1 persen. Maka dapat disimpulkan bahwa ada subjek yang memiliki penyesuaian diri rendah, seluruh subjek memiliki penyesuaian diri yang dikategorikan sedang dan tinggi.

Tabel 7.

Kategorisasi Data Religiusitas 
JESSICA NISSI PANGARIBUAN, WINIDA MARPAUNG \& SRI HARTINI, Penyesuaian

Diri Ditinjau Dari Religiusitas Pada Pengguna Narkoba Di BRSKP (Balai Rehabilitasi Sosial Korban Penyalahgunaan) Napza "Insyaf” Sumatera Utara

\begin{tabular}{ccccc}
\hline Variabel & $\begin{array}{c}\text { Rentang } \\
\text { Nilai }\end{array}$ & Kategori & Jumlah (n) & Persentase \\
\hline \multirow{3}{*}{ Religiusitas } & $\mathrm{x}<100$ & Rendah & 0 & $0 \%$ \\
\cline { 2 - 5 } & $100 \leq \mathrm{x}<150$ & Sedang & 51 & $28.3 \%$ \\
\cline { 2 - 5 } & $\mathrm{x} \geq 150$ & Tinggi & 129 & $71.7 \%$ \\
\hline
\end{tabular}

Berdasarkan kategori pada tabel 7, maka dapat dilihat religiusitas yang dirasakan pada subjek yang masuk dalam kategori rendah berjumlah 0 persen, kategori sedang berjumlah 51 orang dengan persentase sebesar 28.3 persen sedangkan subjek dengan religiusitas yang masuk dalam kategori tinggi berjumlah 129 orang dengan persentase sebesar 71.7 persen. maka dapat disimpulkan bahwa tidak ada subjek yang memiliki skor religiusitas yang rendah, seluruh subjek memiliki religiusitas yang dikategorikan sedang dan tinggi.

Penelitian ini menunjukkan rata-rata subjek yang memiliki penyesuaian diri yang tinggi sebanyak 92 orang atau 51.1 persen, penyesuaian diri yang sedang 87 orang atau 48.3 persen, dan penyesuaian diri yang rendah terdapat 1 orang atau 0.6 persen.

Berdasarkan hasil observasi dan wawancara terhadap subjek menunjukkan penyesuaian diri yang tinggi sebanyak 92 orang atau 51.1 persen. Dapat dilihat dari beberapa subjek yang dalam proses penyesuaian dirinya terlihat sudah mulai dapat memelihara stabilitas mental mereka, sehingga subjek mulai mampu mengatur maupun mengarahkan diri. Kemampuan dalam mengatur diri ini dapat menyadarkan subjek dari keadaan penyimpangan kepribadian. Kemampuan pengaturan diri ini juga dapat mengarahkan kepribadian normal untuk mencapai pengendalian diri. Hal ini sejalan dengan aspek memiliki persepsi yang akurat terhadap realita, dimana beberapa subjek yang sudah mampu memiliki persepsi yang akurat terhadap realita dipakai menjadi konselor oleh pihak rehabilitasi karena dianggap sudah mampu menerima serta menilai kenyataan lingkungan dari luar dirinya secara objektif sesuai dengan pertimbangan rasional, kelak agar dapat membantu para pengguna narkoba lainnya yang masih perlu di bimbingan karena mereka sudah lebih dulu merasakannya.

Dalam penelitian ini menunjukkan dimana rata-rata subjek yang memiliki religiusitas yang tinggi sebanyak 192 orang atau 71.7 persen, religiusitas yang sedang terdapat 51 orang atau 28.3 persen, dan tidak terdapat subjek yang memiliki religiusitas yang rendah dengan persentase 0 persen.

Berdasarkan hasil observasi dan wawancara terhadap subjek menunjukkan religiusitas yang tinggi sebanyak 192 orang atau 71.7 persen. Hal ini dapat dilihat dari subjek yang mengatakan dapat lebih mengenal agama jauh lebih baik dari sebelumnya, dan mengakui bahwasannya belajar agama sangatlah penting bagi kekuatan imannya, dan dimana subjek merasa hidup jauh lebih baik, mampu berpikir positif terhadap keadaan yang telah terjadi dan tidak menyalahkan Tuhan. Akan tetapi peristiwa yang terjadi di maknai karena kesalahan diri sendiri dan sekarang subjek mampu memiliki kemauan untuk bangkit memperbaiki diri. Beberapa subjek juga berkata jauh lebih baik sekarang saya, dalam memiliki waktu untuk mendekatkan diri kepada Tuhan dengan memperbanyak waktu berdoa dan sembahyang sehingga dapat memperkuat iman. Hal ini sangat sejalan dengan aspek dimensi pengetahuan agama. Adanya perubahan kognitif yang terjadi kepada subjek dengan menghilangnya pikiranpikiran negatif kemudian teralihkan untuk mengingat Tuhan. Sehingga menimbulkan rasa 
khusyuk yaitu perubahan suasana hati yang terjadi memunculkan efek positif berupa enjoying (tenang, bahagia, damai) bahkan munculkan rasa cinta kepada Tuhan.

Hasil penelitian pada 180 pengguna narkoba di di BRSKP (Balai Rehabilitasi Sosial Korban Penyalahgunaan) Napza "Insyaf" Sumatera Utara, yang telah menjadi subjek penelitian diperoleh hasil bahwa adanya hubungan positif antara religiusitas dengan penyesuaian diri, dengan koefisien korelasi product moment sebesar $\mathrm{r}=0.390$ nilai $\mathrm{p}$ sebesar $0,000(\mathrm{p}<0,05)$, artinya jika si pengguna narkoba memiliki tingkat religiusitas yang tinggi maka ia akan memiliki penyesuaian diri yang tinggi pula dalam mengadatasikan dirinya dengan lingkungan yang baik. Sebaliknya, jika si pengguna memiliki religiusitas yang rendah maka akan sulit juga baginya dalam menyesuaikan diri dengan lingkungannya

Berdasarkan uraian diatas, maka dapat disimpulkan bahwa penyesuaian diri yang baik dikatakan baik jika seseorang tersebut mampu melakukan respon terhadap lingkungannya secara sadar, efesien, dan sehat. Penjelasan diatas menunjukkan bahwa adanya hubungan positif antara penyesuaian diri dengan religiusitas. Jika tingkat religiusitas seseorang tinggi maka akan semakin mudah baginya untuk menyesuaikan diri dengan lingkungannya. Begitu juga sebaliknya, jika tingkat religiusitas yang dimiliki individu tersebut rendah maka akan sulit baginya untuk menyesuaikan diri dengan lingkungannya.

\section{KESIMPULAN}

Kesimpulan dari penelitian ini ada hubungan positif antara religiusitas dengan penyesuaian diri pada pengguna narkoba di BRSKP (Balai Rehabilitasi Sosial Korban Penyalahgunaan) Napza "Insyaf' Sumatera Utara, dengan menggunakan korelasi product moment $(\mathrm{r})$ sebesar 0.390 dengan $\mathrm{p}$ sebesar $0.000(\mathrm{p}<0.05)$, artinya artinya semakin tinggi tingkat religiusitas yang dimiliki seseorang, maka semakin tinggi juga penyesuaian diri yang dimilikinya. Sebaliknya, semakin rendah tingkat religiusitas yang dimiliki seseorang, maka semakin rendah pula penyesuaian diri yang dimilikinya.

Saran kepada para peneliti yang selanjutnya diharapkan dapat lebih menyempurnakan penelitian ini dengan mengkaji lebih dalam dan terperinci lagi mengenai materi dan faktor lain yang lebih mendukung variabel-variabel dalam penelitian ini seperti spiritual, locus of control, adversity quotient, dukungan sosial keluarga, body image, dukungan sosial teman sebaya, coping, dan harga diri.

\section{DAFTAR PUSTAKA}

Ancok, D., Suroso, F.N. (2005). Psikologi Islam: Solusi Islam atas Problem-problem psikologi. Yogyakarta : Pustaka Pelajar.

Andriyanti, (2015). Hubungan Antara Religiusitas Dengan Penyesuaian Diri di Sekolah Pada Siswa SMP Negeri 3 Pakem Tahun Ajaran 2014/2015. Jurnal Bimbingan dan Konseling, 4.

Dariyo, A. (2004). Psikologi Perkembangan Remaja. Bogor: Ghalia Indonesia 
JESSICA NISSI PANGARIBUAN, WINIDA MARPAUNG \& SRI HARTINI, Penyesuaian

Diri Ditinjau Dari Religiusitas Pada Pengguna Narkoba Di BRSKP (Balai Rehabilitasi Sosial Korban Penyalahgunaan) Napza "Insyaf” Sumatera Utara

Dian, L. \& Endang, S. (2017). Hubungan Antara Religiusitas Dengan Penyesuaian Diri Pada Siswa Dan Siswi Kelas VII Yayasan Pondok Pesantren Futuhiyyah Mranggen Kabupaten Demak. Jurnal Empati, 6, 307-312.

Ghufron, M., \& Risnawita, R. (2015). Teori-Teori Psikologi. Yogyakarta: Ar-Ruzz Media

Gunarsa, D., \& Gunarsa, Y. (2004). Psikologi Perkembangan Anak Dan Remaja. Jakarta: Gunung Mulia

Jalaluddin, R. (2007). Psikologi Agama. Bandung: PT. Mizan Pustaka

Kartono, K. (2000). Hygiene Mental. Bandung: CV. Mandar Maju

Nadzir, A. I. \& Wulandari, N.W, (2013). Hubungan Religiusitas Dengan Penyesuaian Diri Siswa Pondok Pesantren. Jurnal Psikologi Tabularasa, 8, 698-707.

Rokhmatika, L. \& Darminto, E, (2013). Hubungan Antara Persepsi Terhadap Dukungan Sosial Teman Sebaya Dan Konsep Diri Di Sekolah Pada Siswa Kelas Unggulan. Journal Mahasiswa Bimbingan dan Konseling, 1, 149-157.

Siswanto. (2007). Kesehatan Mental. Yogyakarta: CV Andi

Sobur, A. (2003). Psikologi Umum. Bandung: Pustaka Setia

Tarigan, I. J. (2017). Narkotika Dan Penanggulangannya. Yogyakarta: Penerbit Deepublish

Yusuf, S. (2004). Mental Hygiene. Bandung: Pustaka Bani Quraisy

Tribunnews.com. (2017). Wow Ada 350 Ribu Pengguna Narkoba Di Sumatera Utara, Media Bisa Lakukan Ini untuk Memberantasnya. Diunduh dari: http://medan.tribunnews.com/2017/11/13/wow-ada-350-ribu-pengguna-narkoba-disumatera-utara-media-bisa-lakukan-ini-utuk-memberantasnya tanggal 8 oktober 2018 